\title{
The Original Meaning of the Judicial Power
}

Randy E. Barnett

Georgetown University Law Center, rb325@law.georgetown.edu

This paper can be downloaded free of charge from:

https://scholarship.law.georgetown.edu/facpub/839

http://ssrn.com/abstract $=437040$

This open-access article is brought to you by the Georgetown Law Library. Posted with permission of the author. Follow this and additional works at: https://scholarship.law.georgetown.edu/facpub

Part of the Constitutional Law Commons, and the Judges Commons 


\title{
The Original Meaning of the Judicial Power
}

\begin{abstract}
Randy E. Barnett ${ }^{*}$
This Constitution defines the extent of the powers of the general government. If the general legislature should at any time overleap their limits, the judicial department is a constitutional check. If the United States go beyond their powers, if they make a law which the Constitution does not authorize, it is void; and the judicial power, the national judges, who, to secure their impartiality, are to be made independent, will declare it to be void. On the other hand, if the states go beyond their limits, if they make a law which is a usurpation upon the general government, the law is void; and upright, independent judges will declare it to be so. ${ }^{1}$
\end{abstract}

Oliver Elsworth (1788)

The evidence seems to indicate that the Framers did not mean for the Supreme Court to have authority to void acts of Congress. ${ }^{2}$

Leonard Levy (1988)

In the two hundred years between Oliver Elsworth's speech to the Connecticut ratification convention and the statement by the deservedly wellrespected historian Leonard Levy, doubts developed in some quarters concerning the legitimacy of judicial reviewg - doubts I hear expressed wherever I speak on the Constitution. The origin of these doubts appears to lay at the feet of some distinguished legal writers and historians. In addition to Leonard Levy, similar denials or skepticism have been expressed by such well-known legal figures as Charles Beard, William Crosskey, Learned Hand, Charles Hyneman, Jesse Choper, and William Nelson. Although I believe that many constitutional scholars today do not share their views, there exists no definitive originalist refutation of the claim that judicial review was invented by Chief Justice John Marshall in Marbury v. Madison, a claim that has, over the years, crept into the

\footnotetext{
* Austin B. Fletcher Professor, Boston University School of Law [rbarnett@bu.edu]. A revised version of the material presented here will appear in RANDY E. BARNETT, RESTORING THE LOST CONSTITUTION: THE PRESUMPTION OF LiBERTY (Princeton, forthcoming). I extend my thanks to Kate McFarland for her research assistance in the preparation of this article. Permission to photocopy this article for classroom use is hereby granted.

${ }^{1} 2$ Jonathan Elliot, The Debates In The Several State Conventions On The Adoption Of The Federal Constitution 196 (J.B. Lippincott, 1859) [hereinafter Elliot Debates] (Oliver Elsworth in the Connecticut ratification convention January 7, 1788).

${ }^{2}$ LEONARD LEVy, ORIGINAL INTENT AND THE FRAMERS' CONSTITUTION 100 (1988).
} 
legal consciousness and law school classrooms. ${ }^{3}$

In this article, I intend to lay to rest any doubt that, at the founding, the judicial power of the United States included the power of judicial rzeview. I hope to refute any claims that judicial review was invented in Marbury v. Madison, or that, because it is contrary to the original meaning of the Constitution, it must be justified by some nonoriginalist interpretive methodology. I will do so, not by discerning the shadowy and often counterfactual "intentions" of the founding generation, but by presenting as comprehensively as I can what the founders actually said during the constitutional convention and in state ratification conventions, and immediately after ratification. These statements, taken cumulatively, leave no doubt that the founders contemplated judicial nullification of legislation enacted by the states and by Congress. In short, I shall demonstrate once and for all that the original meaning of the "judicial power" in Article I, includes the power of judicial nullification.at least is 4

\section{The SOURCE OF THE CONTROVERSY}

Most people today assume that judges are authorized by the Constitution to declare statutes unconstitutional. Yet the Constitution does not seem to grant this power expressly. Article III says: "The judicial Power of the United States, shall be vested in one Supreme Court, and in such Courts as Congress may from time to time ordain and establish." In sharp contrast with the presidential veto power, ${ }^{5}$ nowhere in the Constitution does it say explicitly that the "Supreme Court, and such inferior courts as may be established by Congress, shall have power to nullify a Law enacted by Congress and signed by the President if the Law is unconstitutional."

The absence of a clearly expressed grant of power has moved some critics of judicial review to question its legitimacy. One of these, Charles Hyneman, argued that the Constitution "expressly endows the president with powers to restrain Congress and the judiciary," and it "expressly endows Congress with powers enabling it to check the president and the judiciary." 6 Nevertheless, "it contains no provision which asserts that the Supreme Court or any other court may exercise a specific power which would restrain the president or Congress in

\footnotetext{
${ }^{3}$ See, e.g. Shawn Gunnarson, Using History to Reshape the Discussion of Judicial Review, 1994 B.Y.U.L. REV. 151, 152 (1994) ("A conventional interpretation of Marbury is that the Supreme Court, under the leadership of Chief Justice Marshall, invented judicial review without supporting precedent or significant historical antecedent.").

${ }^{4}$ How is this for rhetoric likely to induce both citations and attempted refutations by others?

${ }^{5}$ See U.S. CONST. art. I, § 7 ("Every Bill... shall, before it becomes a Law, be presented to the President of the United States; If he approve he shall sign it, but if not he shall return it, with his Objections to the House in which it shall have originated...).

${ }^{6}$ Charles S. Hyneman, The Supreme Court ON TRial 125 (1963).
} 
the exercise of their powers."7 Hyneman contended that the most reasonable inference to draw from the "silence about a restraining power" for the judiciary is that the courts "should not exercise significant restraint on the other two" departments.

Hyneman was not alone. Apart from Leonard Levy, he was joined in his skepticism (in chronological order) by such writers as H.L. Boudin (1911): "There is absolutely no evidence whatever of an intention on the part of [the constitutional convention] to invest the judiciary with any sort of control over federal legislation, or over state legislation in matters admittedly within the legislative competence of the states." Charles Beard (1912): "The direct intention of the framers and enactors not being clearly expressed on this point, we may have recourse to the reason and spirit of the Constitution." 10 Learned Hand (1958): "In spite of authority which I am certainly not qualified to challenge, I cannot, however, help doubting whether the evidence justifies a certain conclusion that the Convention would have so voted, if the issue had been put to it that courts should have power to invalidate acts of Congress."11 William Crosskey: "The rationally indicated conclusion is that judicial review of congressional acts was not intended, or provided, in the Constitution." "12

More recently doubts have been expressed by Jesse Choper (1980): "Whether the framers originally intended to vest the Supreme Court with such an extensive authority has been the subject of powerful and painstaking scholarship. . . . The reported evidence appears - at least to a nonhistorian who has not carefully culled it for himself - to be inconclusive."13 Alexander M. Bickel (1986): "At worst it may be said that the intentions of the Framers cannot be ascertained with finality; that there were some who thought this and some that, and that it will never be entirely clear just exactly where the collective judgment-which alone is decisive - came to rest. In any debate over the force of tradition, such is the most that can be said against the claims of judicial review." ${ }^{\text {14 }}$ William Nelson (2000): "What makes [Marbury] even more important is the absence of any clear plan on

\footnotetext{
${ }^{7} I d$.

${ }^{8} I d$.

${ }^{9}$ H.L. Boudin, 26 Polit. Sc. Qtly. 238, 248 (1911); see also id. ("There is ample historical proof that, whatever the hope of some, from the complete silence of the document, as to possible future development- the great majority of the framers never suspected that a general power of the judiciary to control legislation could be interpreted into the new Constitution. They evidently assumed that such an extraordinary power could not be exercised unless expressly granted.").

${ }^{10}$ Charles Beard, The Supreme Court AND THe Constitution 76 (1912).

${ }^{11}$ LEARNED HAND, THE BILl OF Rights 7 (1958).

${ }^{12}$ William Crosskey, 2 Politics AND the Constitution 1000 (1953).

${ }^{13}$ Jesse Choper, Judicial Review and the National Political Process 62-63 (1980).

${ }^{14}$ AleXander M. Bickel, The Least Dangerous Branch 16 (1986).
} 
the part of the Constitution's framers to provide the Court with this power."

While all these prominent scholars have certainly influenced the legal culture, were they right? While virtually all constitutional scholars accept gthe legitimacy of judicial review, there has developed a veritable cottage industry in in producing defenses of the practice. My purpose is not to rehearse all (or any) of these defenses here. Few of these elaborate analyses would have been necessary, however, if the Constitution contained words whose plain meaning made it irresistibly clear that courts may declare acts of Congress unconstitutional. The absence of this plain language provides an opening for Hyneman et. al. to dismiss such "inferences" as depending "too much on imagination, too little on the plain meaning of plain words." review on highly contestable nonoriginalist interpretive techniques.

Also contributing to the controversy is confusion and disagreement about originalism itself. Some of these skeptics may have been led to their conclusions by their efforts to discern the original intentions of the founders. Given that they involve inquiries into the often hidden and conflicting subjective intentions of myriad people who lived a long time ago, a single prevailing "original intention" is often notoriously difficult to establish beyond dispute. In contrast, I have defended elsewhere the need to look at the original public meaning given the text of the Constitution at the time of the founding, rather than the intentions of those who wrote or ratified it. ${ }^{17}$

A unique or dominant original public meaning is much easier to discern from the historical record so many of the well-known practical difficulties of originalism abate if not disappear with this version. As important, so too do the normative objections to originalism. Original meaning originalism need not reast on any appeal to the authority of long-dead framers. Rather originalism is based on the fact the Constitution is an effort to place rules and restrictions on lawmakers and enforcers; that the Constitution was put in writing to better preserve these restrictions; that purpose for putting these restrictions in writing would largely vanish if lawmakers (or judges) could change the rules by which laws are made. Hence, originalism is justified because we, right here and right now, are or profess to be committed to a written constitution. And the meaning of a written constitution should remain the same until it is properly changed. This last proposition is all that original meaning originalism amounts to.

Original meaning interpretation is not always sufficient to yield a rule of

\footnotetext{
${ }^{15}$ William Nelson, Marbury V. Madison: The Origins and Legacy of Judicial ReView 1 (2000).

${ }^{16}$ HYNEMAN, supra note 6, at 124.

17 See Randy E. Barnett, An Originalism for Nonoriginalists, 45 LoyOLA L. REV. 611 (1999). I expand the normative justification for this approach, and better explain how it works in RANDY E. BARNETT, RESTORING THE LOST CONSTITUTION, chapters 4 \& 5.
} 
law to apply to a case or controversy. When the Constitution's provisions are relatively abstract, there is room for, indeed an imperative to, construe the Constitution in a manner that does not conflict with the original meaning of what the Constitution does say. In other words, where the original meaning of the Constitution is underdeterminate, constitutional construction is needed to provide sufficient determinacy to decide a case, provided that any such construction is consistent with the original meaning of the text.

While some originalists would use the original intentions of the framers or ratifiers to provide specificity, others would look to tradition and history as it has developed since the founding. Unlike original meaning interpretation, neither of these techniques of construction is mandated by a commitment to a written constitution. Elsewhere I explain at greater length the distinction between interpretation and construction and argue that underdeterminate text should be construed in a manner that enhances the qualities that render the Constitution legitimate. ${ }^{18}$ All that is important for present purposes, however, is to note that original meaning provides a frame within which choices must be made in the form of supplementation of abstract textual provisions by constitutional construction. .

With this approach to originalist interpretation (and its limits) in mind, the overwhelming majority of courts and scholars are correct, I submit, to accept the legitimacy of judicial review. Judicial nullification of unconstitutional laws is not only consistent with the frame provided by original meaning, it is expressly authorized by the text and it therefore entirely justified wholly on originalist grounds. Hyneman and other dissenters are wrong, therefore, to reject its historical pedigree. Hyneman does not consider evidence that the original meaning of the "judicial power" found in Article III was more specific than what today is its plain meaning and that, at the founding, it included a power of judicial nullification. If this is established by the weight of the evidence of usage, then some power of judicial review would be justified by an originalist interpretation even if it is not within today's "plain meaning" of the text. In this regard, the "dead" constitution provides a better foundation for judicial review than the ordinary meaning given its words today.

\section{The "Judicial PoWer" InCluded The PoWer OF Nullification}

Far more evidence exists to suggest that the original public meaning of the

\footnotetext{
18 See Randy E. BARnett, Restoring the Lost Constitution, chapters 4 \& 5 . For a discussion of the distinction between interpretation and construction see KEITH E. WHITTINGTON, CONSTITUTIONAL InTERPRETATION: TEXTUAL MEANInG, ORIGINAL INTENT, \& JUdiCIAL REVIEW 7 (1999). For an examination of what I mean by "legitimacy," see Randy E. Barnett, Constitutional Legitimacy, 103 COLUM. L. REV. 111 (2003).
} 
term "judicial power" included the power to nullify unconstitutional legislation than even many constitutional scholars who acknowledge its pedigree realize. In this section I present the evidence to be found in the records of the Constitutional Convention, in the ratification conventions, and in some of the controversies and writings that immediately followed ratification. The evidence in these sources is remarkably uniform.

\section{A. Evidence from the Constitutional Convention}

Several members of the Constitutional Convention in Philadelphia explicitly assumed that the power to nullify unconstitutional legislation resided in the judiciary even before they settled on the particular wording of the various clauses. Several statements were made in the context of a proposed power of Congress to nullify state laws. Roger Sherman of Connecticut argued that a such a power was "unnecessary, as the Courts of the States would not consider as valid any law contravening the Authority of the Union..." James Madison of Virginia favored such a negative because states "will accomplish their injurious objects before they can be . . . set aside by the National Tribunals." ${ }^{20}$ He then cited the example of Rhode Island, where "the Judges who refused to execute an unconstitutional law were displaced, and others substituted, by the Legislature...." ${ }^{21}$ Gouverneur Morris of Pennsylvania argued that the legislative negative was unnecessary because "A law that ought to be negatived will be set aside in the Judiciary department." 22 No one in this discussion disputed the power of the judiciary to set aside unconstitutional laws passed by states.

Nor did anyone question that federal judges would have the same power to set aside unconstitutional legislation from Congress. Much is made by critics of judicial review of the Convention's rejection of the proposed council of revision, inferring from this refusal an intention of the framers that the judiciary defer to legislative will. They rarely mention, however, that the most discussed and influential reason for rejecting the council of revision proposal was the existence of a judicial negative on unconstitutional legislation. So powerful is this and other evidence that it strongly supports the conclusion that judicial nullification was included within the original public meaning of the "judicial power."

During a debate concerning whether judges should be included with the executive in a council empowered to revise laws, the comments of several delegates revealed their assumption that federal judges had the inherent power to

19 James Madison, Notes of Debates in the Federal Convention of 1787; 304 (Norton 1987) [hereinafter NOTES OF DEBATES] (statement of R. Sherman).

${ }^{20} I d$. (statement of J. Madison).

${ }^{21} \mathrm{Id}$. at 305 .

${ }^{22}$ Id. (statement of G. Morris). 
hold federal laws unconstitutional. Luther Martin of Maryland stated that "as to the Constitutionality of laws, that point will come before the Judges in their proper official character. In this character they have a negative on the laws." ${ }^{23}$ George Mason of Virginia observed that "in their expository capacity of Judges they would have one negative.... They could declare an unconstitutional law void." ${ }^{24}$ While he favored the idea of the council, James Wilson of Pennsylvania conceded that there "was weight in this observation" that "the Judges, as expositors of the Laws would have an opportunity of defending their constitutional rights. 25

The assumption that judges possess the inherent power to nullify unconstitutional laws crops up in a variety of other contexts during the Convention. For example, Gouverneur Morris favored ratification of the Constitution by the people in convention because legislative ratification of the new Constitution was prohibited by the terms of the Articles of Confederation. "Legislative alterations not conformable to the federal compact, would clearly not be valid. The Judges would consider them as null \& void."26 James Madison argued that a difference between a league or confederation among states and a constitution was precisely its status as binding law on judges. "A law violating a treaty ratified by a pre-existing law, might be respected by the Judges as a law, though an unwise or perfidious one. A law violating a constitution established by the people themselves, would be considered by the Judges as null \& void." ${ }^{27}$ Hugh Williamson of North Carolina argued that an express prohibition on ex post facto laws by states "may do good here, because the Judges can take hold of it." 28

What is striking in light of these statements is that, throughout the duration of the Convention, I could find no one who disputed the existence of a judicial power to nullify unconstitutional laws. No one. Still, the fact that judicial nullification was taken as given by all members of the Constitutional Convention does not mean everyone liked this power. John Mercer of Maryland said he "disapproved of the Doctrine that the Judges as expositors of the Constitution should have authority to declare a law void." 29 Instead he "thought laws ought to be well and cautiously made, and then to be uncontroulable." ${ }^{\prime 30}$ But Mercer's was a lone voice. Even John Dickenson of Delaware who "was strongly impressed with the remark of Mr. Mercer as to the power of the Judges to set aside the

${ }^{23} I d$. at 340 (statement of L. Martin).

${ }^{24}$ Id. (statement of G. Mason).

${ }^{25} \mathrm{Id}$. at 336-37 (statement of J. Wilson).

${ }^{26}$ Id. at 351 (statement of G. Morris).

${ }^{27} \mathrm{Id}$. at 352-53 (statement of J. Madison).

${ }^{28} \mathrm{Id}$. at 511 (statement of $\mathrm{H}$. Williamson).

${ }^{29} \mathrm{Id}$. at 462 (statement of J. Mercer).

${ }^{30} \mathrm{Id}$. 
law," 31 said he "was at the same time at a loss to know what expedient to substitute." ${ }^{32}$ Gouverneur Morris took issue with Mercer more sharply, stating that he could not agree that the judiciary "should be bound to say that a direct violation of the Constitution was law. A control over the legislature might have its inconveniences. But view the danger on the other side."33

The principal criticism of judicial nullification was not its existence but its weakness. Some framers were not sanguine about the ability of courts to stand up for constitutional principle when necessary. James Wilson thought that Congress should have the power to nullify state laws because "[t]he firmness of Judges is not itself sufficient." 34 Moreover, he argued (in words that assume a judicial power to declare "improper" laws unconstitutional ${ }^{35}$ ) that it "would be better to prevent the passage of an improper law, than to declare it void when passed.",36 Despite this concern, a congressional negative on state laws along with the council of revision was rejected by the Convention, leaving the other structural constraints, including the doctrine of judicial nullification, to keep state and national governments from exceeding their proper powers.

Although I contend that we are not bound by the original intentions of the framers, their expressions of intention are evidence of the original public meaning of the "judicial power." Drafters typically strive to choose words whose public meaning reflects their intentions. This evidence of framers' intentions should also quiet the concerns of those originalists who do care about that intent. More pointedly, originalists who oppose judicial review must abandon original intent originalism because the evidence of such intent is overwhelming. They would also have to disregard the evidence that suggests that the original public meaning of "judicial power" at the time of ratification included judicial review. For the fact that judges were to be empowered to nullify unconstitutional legislation was no secret intention held only by delegates to the Constitutional Convention in Philadelphia.

\section{B. Evidence from the State Ratification Conventions}

The state ratification debates are replete with assertions of the power of judicial nullification. Supporters of the Constitution offered this power as a means of limiting the powers of the general government. Speaking to the Pennsylvania convention, James Wilson stated: "If a law should be made inconsistent with

${ }^{31} I d$. at 463 (statement of J. Dickenson).

${ }^{32} I d$.

${ }^{33} \mathrm{Id}$. (statement of G. Morris).

${ }^{34} \mathrm{Id}$. at 518 (statement of J. Wilson).

${ }^{35}$ A point I stress in Randy E. Barnett, The Original Meaning of the Necessary and Proper Clause, _ U. Pa. J. Con. Law __ (forthcoming).

${ }^{36}$ NOTES OF DEBATES, supra note 18 , at 518. (statement of J. Wilson). 
those powers vested by this instrument in Congress, the judges, as a consequence of their independence, and the particular powers of government being defined, will declare such law to be null and void; for the power of the Constitution predominates. Any thing, therefore, that shall be enacted by Congress contrary thereto, will not have the force of law." 37 To the objection that judges would "be impeached, because they decide an act null and void, that was made in defiance of the Constitution," Wilson replied: "What House of Representatives would dare to impeach, or Senate to commit, judges for the performance of their duty?"

In the Virginia convention, future chief justice John Marshall openly stated the principle of nullification he would later enunciate (and then expand upon) in Marbury v. Madison. If the government of the United States "were to make a law not warranted by any of the powers enumerated," said Marshall, "it would be considered by the judges as an infringement of the Constitution which they are to guard. They would not consider such a law as coming under their jurisdiction. They would declare it void." 38

This article began by quoting Oliver Elsworth's ringing endorsement in the Connecticut convention of the judicial power to nullify unconstitutional acts of both Congress and state legislatures which is worth repeating here:

This Constitution defines the extent of the powers of the general government. If the general legislature should at any time overleap their limits, the judicial department is a constitutional check. If the United States go beyond their powers, if they make a law which the Constitution does not authorize, it is void; and the judicial power, the national judges, who, to secure their impartiality, are to be made independent, will declare it to be void. On the other hand, if the states go beyond their limits, if they make a law which is a usurpation upon the general government, the law is void; and upright, independent judges will declare it to be so.. ${ }^{39}$

The power of the federal judiciary to strike down unconstitutional state laws was also asserted in the North Carolina convention by William Davie, who stated that "Every member will agree that the positive regulations ought to be carried into execution, and that the negative restrictions ought not to [be] disregarded or violated. Without a judiciary, the injunctions of the Constitution may be disobeyed, and the positive regulations neglected or contravened." $40 \mathrm{He}$ then argued that should states impose duties on imported goods, "the Constitution might be violated with impunity, if there were no power in the general

${ }^{37}$ Elliot Debates, supra note 1, at 2:489. (James Wilson in the Pennsylvania ratification convention December 4, 1788).

${ }^{38} I d$. at 3:553 (John Marshall in the Virginia ratification convention, June 20, 1788).

${ }^{39} I d$. at 2:196 (Oliver Elsworth in the Connecticut ratification convention, January 7, 1788) (emphasis added).

${ }^{40}$ Id. at 4:156 (July 29, 1788). 
government to correct and counteract such laws. This great object can only be safely and completely obtained by the instrumentality of the federal judiciary. $" 41$

Even opponents of the Constitution conceded the existence of judicial nullification, though as at the Convention some again questioned its efficacy. In his statement to the legislature of Maryland, Luther Martin said: "Whether, therefore, any laws or regulations of the Congress, any acts of its President or other officers, are contrary to, or not warranted by, the Constitution, rests only with the judges, who are appointed by Congress, to determine; by whose determinations every state must be bound." ${ }^{2}$ In the Virginia ratification convention, Patrick Henry made a similar charge in a manner that suggests he included judicial nullification within the meaning of the word "judiciary":

The honorable gentleman did our judiciary honor in saying that they had firmness to counteract the legislature in some cases. Yes, sir, our judges opposed the acts of the legislature. We have this landmark to guide us. They had fortitude to declare that they were the judiciary, and would oppose unconstitutional acts. Are you sure that your federal judiciary will act thus? Is that judiciary as well constructed, and as independent of the other branches, as our state judiciary? Where are your landmarks in this government? I will be bold to say you cannot find any in it. I take it as the highest encomium on this country, that the acts of the legislature, if unconstitutional, are liable to be opposed by the judiciary. ${ }^{43}$

Also in Virginia, William Grayson, another opponent of the Constitution, observed that "If the Congress cannot make a law against the Constitution, I apprehend they cannot make a law to abridge it. The judges are to defend it." This evidence is another example of how original meaning originalism transcends disputes between contending political parties in ways original intent originalism often cannot. Both sides typically used the same words to describe the same thing. I could find no dissent from this interpretation of the "judicial power" in any of the ratification debates.

\section{Evidence from Immediately After Ratification}

Nor was this conception of judicial power short-lived. Two years after ratification of the Constitution, Representative James Madison delivered his speech to the first session of the House explaining his proposed amendments to the Constitution. In it he asserted the importance of judicial nullification:

\footnotetext{
${ }^{41} I d$. at 157.

${ }^{42} I d$. at 1:380 (Martin Luther in the Maryland ratification convention, January 27, 1788).

${ }^{43} I d$. at 3:324-25 (Patrick Henry in the Virginia ratification convention, June 12, 1788) (emphasis added).

${ }^{44} I d$. at 567 (William Grayson in the Virginia ratification convention, June 21, 1788).
} 
If they are incorporated into the constitution, independent tribunals of justice will consider themselves in a peculiar manner the guardians of those rights; they will be an impenetrable bulwark against every assumption of power in the legislative or executive; they will be naturally led to resist every encroachment upon rights expressly stipulated for in the constitution by the declaration of rights. ${ }^{45}$

No one in Congress rose to object to this assertion of "judicial power."

Similarly instructive is the understanding of Thomas Jefferson. Because Jefferson was in France during the drafting and ratification of the Constitution, some originalists disparage any reliance upon his views. Yet the very fact that Jefferson did not participate in writing or debating the meaning of the Constitution makes his reading of the text relevant to an assessment of its original public meaning. Added to this is the fact that Jefferson was less of a partisan at this time. While he generally supported the Constitution, Jefferson had serious reservations about several of its features particularly the absence of a bill of rights and rotation in office (what we call today "term limits"). As he put it, "I am neither federalist nor antifederalist; .... I am of neither party, nor yet a trimmer between parties. 44

Of special interest are statements in two letters written closely in time to James Madison. In the first, a well-known exchange, Jefferson attempts to persuade Madison of the value of a bill of rights, which Madison had previously disparaged in a letter to Jefferson as mere "parchment barriers." contended that "experience proves the inefficacy of a bill of rights on those occasions when its controul is most needed." ${ }^{48}$ In Jefferson's reply he invoked the importance of judicial nullification:

In the arguments in favor of a declaration of rights, you omit one which has great weight with me, the legal check which it puts into the hands of the judiciary. This is a body, which if rendered independent, and kept strictly to their own department merits great confidence for their learning and integrity. ${ }^{49}$

Jefferson's affirmation of a judicial power to nullify unconstitutional laws is of special significance in light of an earlier objection to the Constitution he had made in a letter to Madison: "I like the negative given to the Executive with a

\footnotetext{
${ }^{45} 1$ AnNALS OF CONG. 457 (Joseph Gales ed., 1790).

4614 The PaPers of Thomas JefFerson 651. (Julian P. Boyd et al., eds., Princeton University Press 1950) (Letter to Francis Hopkinson, March 13, 1789) [hereinafter JEFFERSON PAPERS].

4711 PAPERS OF JAMES MADISON 297 (University of Chicago Press, 1961) (Letter to Thomas Jefferson, October 17, 1788) [hereinafter MADISON PAPERS] ("Repeated violations of these parchment barriers have been committed by overbearing majorities in every State."). ${ }^{48} \mathrm{Id}$.

${ }^{49}$ JefFerson PAPERS, supra note 45, at 14:659 (Letter to James Madison, March 15, 1789).
} 
third of either house, though I should have liked it better had the Judiciary been associated for that purpose, or invested with a similar and separate power. ${ }^{, 50} \mathrm{~A}$ judicial "negative," which the Constitution omitted, like the presidential veto to which Jefferson referred, could be exercised for any reason, not just on the ground that a law was unconstitutional. From Jefferson's later exchange with Madison asserting the existence of judicial review, we can discern that the omission of judicial negative or veto on legislation in the Constitution did not undermine Jefferson's view that the judicial power included a power to nullify unconstitutional laws.

Finally, Madison's early skepticism of the merits of judicial review confirms, rather than undermines, the conclusion that the original meaning of the "judicial power" included the power of nullification. In his Observations on the "Draught of a Constitution for Virginia", written within days of his "parchment barriers" letter to Jefferson, Madison proposed that vetoed or nullified bills reenacted by specified supermajorities in either or both houses should become law over the objection of either the executive or the judiciary. "It sd. not be allowed the Judges or the Ex to pronounce a law thus enacted, unconstitul. \& invalid.",51 Nevertheless, he acknowledges that in the Constitution then pending ratification, only the executive veto may be overridden by a supermajority of both houses. As a result,

In the State Constitutions \& indeed in the Fedl. one also, no provision is made for case of a disagreement in expounding them; and as the Courts are generally the last in making their decision, it results to them, by refusing or not refusing to execute a law to stamp it with its final character. This makes the Judiciary Dept paramount in fact to the Legislature, which was never intended, and can never be proper. ${ }^{52}$

I disagree with Madison here. Being last does not make the judiciary in any sense "paramount" but merely equal to the other branches. After all, Congress may refuse to enact a law because it deems it to be unconstitutional and, because it is first, the bill never reaches the courts who may disagree. This does not render Congress paramount to the courts. By the same token, if the president vetoes a bill and his veto is sustained, the courts do not get to reverse that decision and uphold the bill as constitutional. Instead, in our system, absent a legislative supermajoritarian override of a presidential veto, all three branches must concur before it is found constitutional. Any one branch may scuttle a law because it alone deems it unconstitutional. Of course, as we have seen, by the time he

\footnotetext{
${ }^{50} I d$. at 12:440 (Letter to James Madison, December 20, 1787).

${ }^{51}$ MADISON PAPERS, supra note 46, at 11:293 ("Observations on the 'Draught of a Constitution for Virginia,"”ca. October 15, 1788).

${ }^{52}$ Id.
} 
introduced his proposed amendments in the first Congress, Madison came to be persuaded by Jefferson (and presumably others) to change his mind on the propriety of judicial nullification and he strongly asserted the need for such a power.

Moreover, by bemoaning this feature of the Constitution as written, Madison assumes, rather than denies, that the "judicial power" includes the power of nullification. Observing so influential a supporter of the Constitution taking issue with its propriety here, rather than denying that "judicial power" includes the power of nullification, is particularly potent evidence of its original meaning.

That Madison's objection confirms the original meaning of the "judicial power" is also another vindication of the practicality of original meaning originalism and shows its advantages over original intent. While Madison's intent may have changed or conflicted with that of other framers, the meaning of the term "judicial power" in the Constitution remained constant and readily discernable by historical evidence. This example illustrates, like the statements of antifederalists discussed above, how original meaning can be discerned from the contemporaneous statements of those who oppose no less than those who support a particular provision.

I have presented so many different statements asserting the existence of the power of judicial nullification because there are those today who question whether the doctrine was widely held by the founding generation. Like Charles Hyneman, they suggest that it was invented in 1803 by John Marshall in Marbury v. Madison. Given the weight of the historical evidence (which Hyneman, for example, does not discuss), their argument ultimately rests on the fact that the power of nullification is not explicit in the Constitution. Rarely do they examine the original meaning of "judicial power," however, choosing to rely instead on the "plain meaning" that term has today.

\section{Construing the Power From Other Provisions of the Text}

A power of judicial nullification is warranted not only by interpretation of the term "judicial power" but also by construing other provisions. According to Article III, Section 2: "The judicial Power shall extend to all Cases, in Law and Equity, arising under this Constitution and Laws of the United States.... [and] to Controversies to which the United States shall be a party." Second, the Supremacy Clause of Article VI provides that "This Constitution, and the Laws of the United States which shall be made in Pursuance thereof; and all Treaties made, or which shall be made, under the Authority of the United States, shall be the supreme Law of the Land; and the Judges in every State shall be bound thereby, any Thing in the Constitution or Laws of any State to the Contrary notwithstanding." 
These provisions support the following construction: Courts are empowered under Article III to decide "all cases ... arising under this Constitution and Laws of the United States." When deciding such a case, a court is required to apply the laws that are applicable to the case at hand. In cases where both the Constitution and a statute apply and the latter is in conflict with the former, the court must decide which is a superior authority. The Supremacy Clause suggests that the Constitution should take precedence over a statute. (I say "suggests," because the Supremacy Clause speaks of the superiority of the Constitution only to state laws and constitutions, not to acts of Congress.) Therefore, when the court finds that a statute is in conflict with the Constitution, it is bound to obey the Constitution and disregard the statute.

This was the construction provided by Alexander Hamilton in Federalist 78:

The interpretation of the laws is the proper and peculiar province of the courts. A constitution is, in fact, and must be regarded by the judges as, a fundamental law. It therefore belongs to them to ascertain its meaning as well as the meaning of any particular act proceeding from the legislative body. If there should happen to be an irreconcilable variance between the two, that which has the superior obligation and validity ought, of course, to be preferred; or, in other words, the Constitution ought to be preferred to the statute, the intention of the people to the intention of their agents. ${ }^{53}$

Why is the Constitution "superior" to an act of Congress? "There is no position which depends on clearer principles than that every act of a delegated authority, contrary to the tenor of the commission under which it is exercised, is void. No legislative act, therefore, contrary to the Constitution, can be valid." 54 Moreover, Hamilton argued: "To deny this would be to affirm that the deputy is greater than his principal; that the servant is above his master; that the representatives of the people are superior to the people themselves; that men acting by virtue of powers may do not only what their powers do not authorize, but what they forbid." 55 Hamilton also rejected the idea that this construction makes the judicial branch "superior" to Congress.

Nor does this conclusion by any means suppose a superiority of the judicial to the legislative power. It only supposes that the power of the people is superior to both, and that where the will of the legislature, declared in its statutes, stands in opposition to that of the people, declared in the Constitution, the judges ought to be governed by the latter rather than the former. They ought to regulate their

${ }^{53}$ The Federalist No. 78, at 467 (Alexander Hamilton) (Clinton Rossiter ed., Penguin Books 1961).

${ }^{54} \mathrm{Id}$.

${ }^{55} \mathrm{Id}$. 
decisions by the fundamental laws rather than by those which are not fundamental. ${ }^{56}$

Hamilton's argument is undoubtedly a constitutional construction rather than a straightforward interpretation of the "judicial power." This becomes even clearer when he bases his analysis on the premise that "The complete independence of the courts of justice is peculiarly essential in a limited Constitution. By a limited Constitution, I understand one which contains certain specified exceptions to the legislative authority; such, for instance, as that it shall pass no bills of attainder, no ex post facto laws, and the like." ${ }^{57}$ If the legislature is to be limited in this manner, who besides the courts can police this limitation?

Limitations of this kind can be preserved in practice no other way than through the medium of courts of justice, whose duty it must be to declare all acts contrary to the manifest tenor of the Constitution void. Without this, all the reservations of particular rights or privileges would amount to nothing. ${ }^{58}$

Notice that nothing in this rationale for judicial review would empower the judiciary to permit Congress to exceed the limits on its powers by changing via "interpretation" the written Constitution. To the contrary, this whole justification for judicial review assumes that the Constitution provides written limitations that Congress is to follow and judges to enforce. In short, this construction permitting judicial nullification provides still more support for originalist interpretation.

Is Hamilton's argument for judicial review undermined because it is a "mere" construction rather than a straightforward interpretation of the text? Hardly. First, it is entirely consistent with evidence of the original meaning of the "judicial power." Second, the contrary position that the Constitution's silence is to be taken as support for congressional supremacy is also a construction. Indeed, Hamilton himself appreciated this:

If it be said that the legislative body are themselves the constitutional judges of their own powers and that the construction they put upon them is conclusive upon the other departments it may be answered that this cannot be the natural presumption where it is not to be collected from any particular provisions in the Constitution. It is not otherwise to be supposed that the Constitution could intend to enable the representatives of the people to substitute their will to that of their constituents. It is far more rational to suppose that the courts were designed to be an intermediate body between the people and the legislature in order, among other things, to keep the latter within the limits assigned to their

${ }^{56} I d$. at $467-68$.

${ }^{57} I d$. at 466 .

${ }^{58} \mathrm{Id}$. 
authority. ${ }^{59}$

In this passage, Hamilton shows that the opposing view is itself one of construction, but a construction inferior to the one he advocates. Where the text of the Constitution is silent ("where it is not to be collected from any particular provisions in the Constitution") and therefore not subject to straightforward interpretation, we ought not adopt a construction ("this cannot be the natural presumption") that Congress is to be "the constitutional judges of their own powers and that the construction they put upon them is conclusive upon the other departments." Rather, in light of the purposes for which the Constitution was adopted and the limitation of power it imposes upon Congress, "It is far more rational to suppose that the courts were designed to be an intermediate body between the people and the legislature in order, among other things, to keep the latter within the limits assigned to their authority." 60

However, this last formulation that courts were designed "to keep [the legislature] within the limits assigned to their authority" is vague. Because Hamilton does not add "by nullifying the enforcement of unconstitutional statutes that come before them," his formulation could also be taken to justify a broader power to order or compel other branches of the government to keep them "within the limits assigned to their authority." To claim this power for the judiciary would be to move beyond judicial nullification to something that could be called judicial supremacy. Hamilton, of course, said no such thing and, in context, it is not clear that such meaning could fairly be attached to his words. Yet in 1803, this power was claimed for the courts in the landmark case of Marbury v. Madison.

\section{JUdicial SUPREMACY IS A CONSTRUCTION}

We speak today of the power of "judicial review," not judicial nullification. The modern power of judicial review is not limited to refusing to enforce an unconstitutional law being applied to an individual a power that is warranted by the original meaning of the "judicial power." Modern judicial review also includes a power to command or order other branches of the government to follow the judiciary's interpretation of the Constitution a power that is sometimes called "judicial supremacy." Although I am not entirely satisfied with this term, ${ }^{61}$ I will use it to distinguish between a conception of judicial review limited to judicial nullification and one that extends as well to the power to command or direct other branches and levels of government to conform

\footnotetext{
${ }^{59} I d$. at 467.

${ }^{60} \mathrm{Id}$.

61 "Supremacy" strikes me as needlessly pejorative. I would prefer a term to describe this power that does not prejudge the outcome of an inquiry into its propriety.
} 
to the judiciary's view of what the Constitution requires.

The distinction between judicial nullification and judicial supremacy can be hard to grasp because nullification seems like a subset of supremacy. A power of nullification gives the judiciary the last word on whether a statute is "law" that is binding on the individual and this seems like "supremacy," but the appearance is misleading. The explicit division of the government into three departments, commonly said to be "coequal" (though this term also does not appear in the text), suggests that the judicial branch must reach its own decision on what the Constitution requires in cases of conflict between the Constitution and an act of Congress when deciding which to enforce. A power of nullification is not one of supremacy, but one of judicial equality. Were it absent, the legislative and executive branches alone would decide on the constitutionality of their laws. Judges would have to merely take their orders. This would render the judiciary inferior to the other branches rather than their equal.

The confusion of judicial nullification with judicial supremacy arises if one ignores the proposition that judicial negation is not legislation. ${ }^{62}$ If Congress refuses to enact a statute, perhaps because in its opinion it would be unconstitutional, it does not matter if a court would uphold it as constitutional. Courts cannot mandate the passage of a statute. On the issue of which statutes to enact the legislative power the legislature is "supreme." Only if the Congress enacts a measure because enough of its members believe it to be constitutional (or do not care) and the president signs the bill believing it is constitutional (or does not care) may the Court have the opportunity to express its opinion on its constitutionality. A court's power to negate unconstitutional legislation renders it equal, not superior, to the other branches.

Just as a power to negate legislation does not imply a power to enact it, neither does it imply a judicial power to mandate that the executive branch exercise its powers in a particular mode. True, judicial nullification would extend to refusing to hold a person liable for disobeying an unconstitutional command of the executive branch. Nullification, however, does not include the further power to order or "mandate" that someone act in a particular manner or to desist from acting in a manner a court finds to be unconstitutional. Whether or not this additional power can be justified on the basis of interpretation or construction is a separate question. While historical evidence strongly supports the conclusion that the original meaning of "judicial power" included the power to nullify, there is little if any evidence to support a claim that the original meaning of "judicial power" also included a power to command other branches.

Nor was such a power actually exercised by the Supreme Court in Marbury v. Madison. ${ }^{63}$ This famous case grew out of legislation enacted by a

${ }_{62}^{62}$ thank Leonard Liggio for providing this helpful formulation.

${ }^{63} 5$ U.S. 137 (1803). 
lame-duck Congress dominated by Federalists to create numerous judicial positions that could be filled with Federalists by outgoing President Adams before the newly elected Republican Thomas Jefferson could assume the presidency. In a bizarre twist by today's lights, all these "midnight commissions" had been sealed by John Marshall himself who was not only chief justice, but also the outgoing secretary of state and delivered by his brother James. In the haste to seal and deliver the commissions, Marbury's was left behind. At the instruction of incoming President Jefferson, James Madison, the incoming secretary of state, refused to deliver it.

Marbury then brought suit in the Supreme Court to issue a writ of mandamus to compel the secretary of state "either to deliver the commission, or a copy of it from the record." Judiciary Act that authorized the Court to grant writs of mandamus on government officials exceeded the powers of Congress and was unconstitutional. ${ }^{65}$ By avoiding the issue of whether a judicial command of this kind to the executive branch would exceed the judicial power, Marshall needed only to justify in his opinion the judicial power to nullify the Judiciary Act as beyond the powers of Congress to enact. Although this conclusion could have been well-supported by evidence of the original meaning of the "judicial power," Marshall's opinion in Marbury is entirely an exercise in constitutional construction - and perhaps this absence of originalist justification is the source of the cloud over the judicial power of nullification ever since..

Marshall begins by recourse to "certain principles, supposed to have been long and well established." 66 Among these is the principle that the Constitution is "superior law ... unchangeable by ordinary means." ${ }^{\text {"67 }}$ Although the text says the Constitution is superior to state constitutions and statute, it does not say it is superior to acts of Congress. Nor does it say that it cannot be changed by ordinary means, though this can be implied by the extraordinary mechanisms of amendment it provides in Article V. Marshall notes that "all those who have framed written constitutions contemplate them as forming the fundamental and paramount law of the nation." ${ }^{, 68} \mathrm{He}$ concludes from all this that "legislative act contrary to the constitution is not law." 69

Marshall then claims that it is "emphatically the province and duty of the

\footnotetext{
${ }^{64} \mathrm{Id}$. at 173.

${ }^{65}$ The ruling was based on the distinction between "original" and "appellate" jurisdiction explicit in Article III rather than on any inherent constitutional limitation on the judiciary. The Court found that the act improperly allowed for such relief in cases initiated in the Supreme Court instead of only those cases that the Court heard on appeal from the suit commenced in lower court.

${ }^{66} 5$ U.S. at 176.

${ }^{67}$ Id. at 177.

${ }^{68} \mathrm{Id}$.

${ }^{69} \mathrm{Id}$.
} 
judicial department to say what the law is. Those who apply the rule to particular cases, must of necessity expound and interpret that rule."70 Like Hamilton, Marshall notes that "[i]f two laws conflict with each other, the courts must decide on the operation of each." I1 In such a case, "the court must determine which of these conflicting rules governs the case. That is of the very essence of judicial duty.",72 Like Hamilton, he finds the answer in the superior authority of the Constitution. "If, then, the courts are to regard the constitution, and the constitution is superior to any ordinary act of the legislature, the constitution, and not such ordinary act, must govern the case to which they both apply."73

Marshall emphasizes that to hold otherwise would be to thwart the idea of a written constitution and would violate the first principles of this particular system of government:

This doctrine would subvert the very foundation of all written constitutions. It would declare that an act which, according to the principles and theory of our government, is entirely void, is yet in practice, completely obligatory. It would declare, that if the legislature shall do what is expressly forbidden, such act, notwithstanding the express prohibition, is in reality effectual. It would be giving to the legislature a practical and real omnipotence, with the same breath which professes to restrict their powers within narrow limits. It is prescribing limits, and declaring that those limits may be passed at pleasure. ${ }^{74}$

Most modern admirers of Marshall and of Marbury fail to realize how the "principles and theory of our government" he advances for the power of judicial nullification also argue strongly for originalist interpretation. For only if the Constitution has a meaning independent of the judiciary, and that must remain the same until properly changed, does the existence of the "superior" law that is the written Constitution justify judges' nullifying the "ordinary" authority of a statute.

Not until the end of his opinion does Marshall reinforce his analysis with "additional arguments" furnished by inferences drawn from "the peculiar expressions of the constitution of the United States." 75 With respect the "judicial power," Marshall argues that it "is extended to all cases arising under the constitution." to say that, in using it, the constitution should not be looked into? That a case arising under the constitution should be decided without examining the instrument

\footnotetext{
${ }^{70} I d$.

${ }^{71} I d$.

${ }^{72} I d$. at 178 .

${ }^{73} \mathrm{Id}$.

${ }^{74} \mathrm{Id}$.

${ }^{75} \mathrm{Id}$.

${ }^{76} \mathrm{Id}$. at 178 .
} 
under which it arises?"77

Marshall then lists various explicit prohibitions and restrictions in the Constitution and concludes, "From these, and many other selections which might be made, it is apparent, that the framers of the constitution contemplated that instrument, as a rule for the government of courts, as well as of the legislature., ${ }^{, 78}$ In this way, "the particular phraseology of the constitution of the United States confirms and strengthens the principle, supposed to be essential to all written constitutions, that a law repugnant to the constitution is void; and that courts, as well as other departments, are bound by that instrument.",79

Notice that none of Marshall's arguments presented to this point support a judicial power to command another coequal branch of government. Indeed, he explicitly denies that the court may issue a writ of mandamus to the president himself, confining his attention only to whether the secretary of state can be compelled to perform a merely "ministerial act." He concludes that

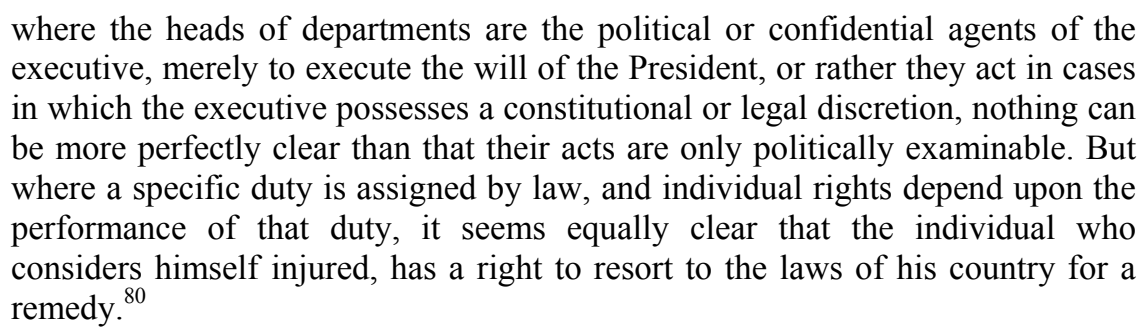

Later in the opinion Marshall denies that a court may "enquire how the executive, or executive officers, perform duties in which they have discretion. Questions, in their nature political, or which are, by the constitution and laws, submitted to the executive, can never be made in this court." 81

Because I do not wish to question whether courts may properly compel executive branch officials to perform acts required by law, I shall not rehearse here all the arguments made by Chief Justice Marshall on behalf of such a judicial power. My point is simply that, unlike the case of judicial nullification, there is little or no evidence that such a power can be justified by the original meaning of the "judicial power," and Marshall offered none. Further, because it held that the power was improperly granted to the Court by Congress, any suggestion in Marbury that a court has power to mandate behavior is dicta.

Marshall's dicta that courts may sometimes have such a power is a construction, rather than an interpretation, of the Constitution, though this is not

\footnotetext{
${ }^{77} \mathrm{Id}$. at 179 .

${ }^{78} \mathrm{Id}$. at $179-80$.

${ }^{79} I d$. at 180 (emphasis added).

${ }^{80} \mathrm{Id}$. at 166.

${ }^{81} \mathrm{Id}$. at 170 .
} 
to say that it is necessarily improper. Also a constriction is the contrary position favored, for example, by President Jefferson who was of the opinion that federal courts "cannot issue a mandamus to the President or legislature, or to any of their officers." " Although the writ existed at common law, "the constitution [controls] the common law in this particular." 83 Because he was speaking of judicial supremacy, not judicial nullification, Jefferson was not contradicting his earlier endorsement of judicial review as some have charged. ${ }^{84}$ To resolve this dispute would require an inquiry into whether a constructive judicial power of mandamus sometimes or always conflicts with the original meaning of the text and, if not, whether such a power enhances or detracts from constitutional legitimacy. ${ }^{85}$ I express no opinion on this issue here.

\section{CONCLUSION}

We are now in a position to understand why the Constitution did not contain a passage reading something like: "The Supreme Court, and such inferior courts as may be established by Congress, shall have power to nullify a Law enacted by Congress and signed by the President if the Law is unconstitutional." The evidence from the Constitutional Convention and from the state ratification conventions is overwhelming that the original public meaning of the "judicial power" included the power to nullify unconstitutional laws. In contrast, because the "executive power" did not include the inherent power to veto legislation, it had to be added expressly. So too did the legislative override.

The evidence found in these crucial records of public meaning is so consistent that the discovery of a few counterexamples would not undermine this conclusion. Nevertheless, I found no such counterexamples in my search through these records (though one never can be completely sure about what one has missed). Will the evidence marshaled here end all further controversy over

8210 The Writings of Thomas JefFerson 140 (Paul Leicester Ford, ed., Putnam's 1892-99) (Letter to Spencer Roane, September 6, 1819).

${ }^{83} \mathrm{Id}$.

${ }^{84}$ Jefferson has been accused of changing his position on judicial review when Federalist judges obstructed his political agenda. A more nuanced account is provided by David Mayer, who shows that while Jefferson never wavered in his support for judicial nullification, his objection was to affirmative judicial interference with the "Revolution of 1800." See DaVID N. MAYER, THE CONSTITUTIONAL THOUGHT OF THOMAS JEFFERSON 257-94 (1994).

${ }^{85}$ It might, for example, be improper to issue a mandamus to the President or Congress perhaps because it violates the original textual allocation of executive or legislative powers, but not improper for a court to command some lesser employee of another branch. I offer this possibility only to illustrate the potential relationship between interpretation and construction in answering this question. Of course it is also possible to advance additional evidence that judicial supremacy was within or in conflict with the original meaning of the judicial power and therefore is mandated or prohibited by the text. 
whether judicial review is authorized by the original meaning of the text? My tongue-in-cheek rhetoric to one side, longstanding academic debates are rarely settled so cleanly. Still, one of the virtues of original meaning originalism is that those seeking to dissent from this conclusion must go out and find direct evidence of original meaning in the form of statements from the conventions (or, less meaningfully, from elsewhere) to the contrary. Speculation under the guise of historical "context" or counterfactual channeling the framers will not do. I look forward to examining the fruits of their labor. 